\title{
Founders of the RAS:
}

Francis Baily

\author{
You may have \\ heard of his Beads, \\ but there was \\ a lot more to \\ Francis Baily, as \\ Mike Edmunds \\ recounts in the \\ first of his Brief \\ Lives, celebrating \\ the founders and \\ history of the Royal \\ Astronomical \\ Society.
}

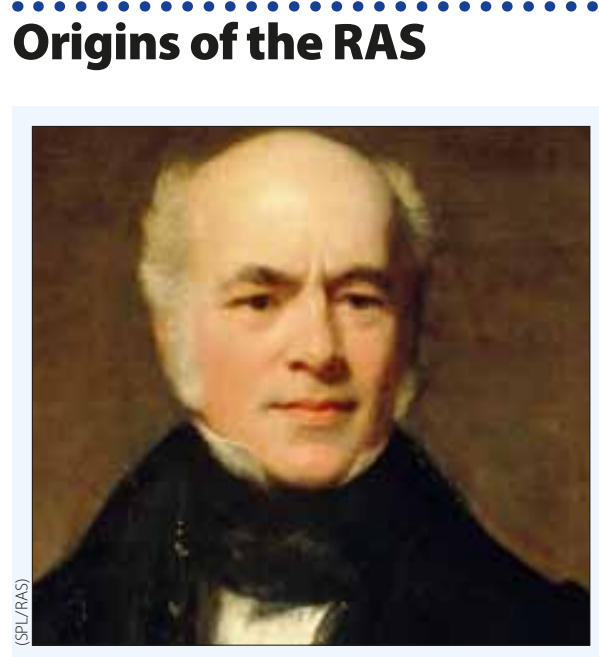

In 2020, the RAS celebrates 200 years since its founding in Regency England, two weeks before the old and dotty King George III died, at last allowing his regent son to ascend the throne as George IV. It was five years since the Battle of Waterloo, and five years before the opening of the first public railway worked by steam locomotives. The idea of a society seems to have been proposed by the Rev. William Pearson in 1812, but it took the practical approach of Francis Baily (left) to start the ball rolling. On 20 January in the particularly cold winter of 1819/20, "the Astronomical Society of London" began with 14 men meeting at the Freemason's Tavern. The youngest was 24 years old, the oldest 65 . Who were they? What was their astronomical world like? Why start a society then? This series of short articles running up to 2020 aims to sketch both the men and their times.

\section{AUTHOR}

Michael Edmunds, School of Physics and Astronomy, Cardiff University, UK.

\section{FURTHER READING}

Baily $F 1836$ On a remarkable

phenomenon that occurs on total and partial eclipses of the Sun Mem. R. Ast. Soc. $\mathbf{X} 1$

Baily F 1856 Journal of a Tour in Unsettled Parts of North America in 1796 and 1797 de Morgan A (ed.) http://ia802709. us.archive.org/18/items/journaloftour inu00bail/journaloftourinu00bail.pdf Clerke AM 1885-1900 Francis Bailey Dictionary of National Biography http:// en.wikisource.org/wiki/Baily,_Francis_ (DNBO0)

Herschel JFW 1844 Memoir Mon. Not. R.Ast.Soc. $\mathbf{6} 89$
$\mathbf{U}$ nless perhaps involved in the wilder fringes of cosmological speculation, you will not hear a present-day astronomer claiming that they "at night never slept but with a pair of pistols under my pillow". Such, however, was the situation of Francis Baily (1777-1844) at the end of the 18th century when, in his early 20s, he undertook a long "gap-year" involving some of the wilder parts of the US.

Born in Newbury, Berkshire, Baily had left school at the age of 14 and been apprenticed into a mercantile profession in the City of London. When he returned from the US, he wanted to continue as an explorer to Africa, but could not. So he went back to the City and gained great success both as a stockbroker and as a writer on interest and annuities. He began to publish on astronomy from 1811 and by his late forties, a few years after his involvement in the formation of the Astronomical Society of London (subsequently to become the RAS), he had earned enough to give up his financial career and devote himself to science.

This was to be no gentle or dilettante retirement, for he worked with great commitment and attention to detail. Reform of star catalogues won him the Society's Gold Medal in 1827, followed by a second one in 1843 for a Herculean repeat and improvement of the so-called Cavendish Experiment to measure the mean density of the Earth (the experiment was originally invented by John Mitchell, as pointed out by Sir John Herschel in his superb biographical memoir of Baily in Monthly Notices).

Baily is perhaps best known for his influential description of the 1836 eclipse, which he observed near Jedburgh in the Scottish borders, probably the first mention in print of the effects of the irregularity of the lunar limb: "... a row of lucid points, like a string of bright beads ... suddenly formed round that part of the circumference of the moon that was about to enter ... on the sun's disc" ${ }^{\prime \prime}$ these were Baily's Beads.

His interests were wide. From studying John Flamsteed's papers, Baily rescued the first Astronomer Royal's reputation. He was prescient in recognizing the potential of mechanical computation as ..... early as 1824, enthusing that "Mr Babold Medal in 1827 followed by a second one in 1843" bage's invention is one of the ... most important in modern times". Although driven by the desire for calculation and printing of astronomical tables that were more reliable, one cannot but wonder if Baily's commercial experience was also a spur here, particularly as he drew a parallel with "the introduction of the steam engine".

\section{Popular}

He must have been a popular and respected figure - elected four times as RAS President, with his eight years being a record for presidential service. Yet what is one to make of Herschel's comment that "his talents were great, but rather solid and sober rather than brilliant"? Perhaps there was a little professional jealousy at Baily's irritating ability to finish one task before starting another.

Increasing deafness may have contributed to him being knocked down by a horse and rider in 1841, which put into a coma for a week. He appeared to make a full recovery and lived on for three years. He never married, residing for many years in Tavistock Place, London, with his sister Elizabeth. A plaque in his memory was unveiled in Newbury town centre in February 2016. 